\title{
Article
}

\section{Mitigating externalities of terrorism on tourism: global evidence from police, security officers and armed service personnel}

\author{
Asongu, Simplice A. and Jacinta, Nwachukwu
}

Available at http://clok.uclan.ac.uk/24337/

Asongu, Simplice A. and Jacinta, Nwachukwu ORCID: 0000-0003-2987-9242 (2019) Mitigating externalities of terrorism on tourism: global evidence from police, security officers and armed service personnel. Current Issues in Tourism, 22 (20). pp. 2466-2471. ISSN 1368-3500

It is advisable to refer to the publisher's version if you intend to cite from the work. http://dx.doi.org/10.1080/13683500.2018.1527825

For more information about UCLan's research in this area go to http://www.uclan.ac.uk/researchgroups/ and search for <name of research Group>.

For information about Research generally at UCLan please go to http://www.uclan.ac.uk/research/

All outputs in CLoK are protected by Intellectual Property Rights law, including Copyright law. Copyright, IPR and Moral Rights for the works on this site are retained by the individual authors and/or other copyright owners. Terms and conditions for use of this material are defined in the policies page.

\section{CLoK}

Central Lancashire online Knowledge www.clok.uclan.ac.uk

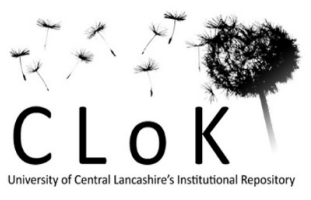




\title{
Mitigating externalities of terrorism on tourism: global evidence from police, security officers and armed service personnel
}

\author{
Forthcoming: Current Issues in Tourism
}

\author{
Simplice A. Asongu \\ Development Finance Centre, Graduate School of Business, \\ University of Cape Town Cape Town South Africa. \\ E-mails: asongusimplice@yahoo.com / asongus@afridev.org
}

\author{
Jacinta C. Nwachukwu \\ Lancashire School of Business and Enterprise, \\ University of Central Lancashire, Preston, PR2 2HE, \\ United Kingdom \\ Email: j.ch.nwachukwu@gmail.com
}

\begin{abstract}
In this paper, we investigate the role of security officers, the police and armed service personnel in dampening the effect of terrorism externalities on tourist arrivals. The temporal and geographic scopes are respectively 2010-2015 and 163 countries. Four terrorism measurements are used. They include the number of: incidents, injuries, fatalities and property damages. The main findings indicate that armed service personnel can effectively be used to modulate the damaging influence of all four terrorism externalities in order to achieve a positive net effect on tourist arrivals. Conversely, the corresponding moderating role of security officers and the police is not statistically significant. Moreover, violent demonstrations and homicides have a harmful effect on tourist arrivals while the number of incarcerations displays the opposite effect. Policy implications are discussed.
\end{abstract}

JEL Classification: D74; Z32; Z38

Keywords: Terrorism; Peace; Tourism 


\section{Introduction}

The positioning of this study builds on three main tendencies in academic and policymaking circles. They are: (i) the growing challenge of terrorism across the world, (ii) the policy relevance of tackling the consequences of terrorist attacks on economic development outcomes and (iii) gaps in the tourism literature.

First, with respect to the evolving challenge of terrorism, in recent decades, the phenomena of terrorism has been on the rise across the globe. The burgeoning phenomenon has partly been fueled by the 2011 Arab Spring and corresponding negative externalities (GTI, 2014; Asongu et al., 2018a).

Second, the policy importance of addressing the negative externalities associated with terrorism fundamentally builds on corresponding costs and consequences. On the one hand, terrorists' activities inflict substantial adverse consequences on economic development outcomes. On the other, the cost of fighting terrorism is relevant to policy because the alternative investments forgone could be spent within the framework of socio-economic investments that are imperative for the achievement of sustainable development goals in the post-2015 development agenda.

Third, the literature on tourism has largely focused on the determinants of tourism without investigating how the destructive influence of such violent activities could effectively be mitigated with policy variables (Saha \& Yap, 2013; Alvarez \& Campo, 2014; Mehmood et $a l .$, 2016). This study departs from this existing literature by focusing on how the adverse consequences of policy syndromes (such as terrorism externalities) on tourism could be effectively modulated with policy variables (in terms of the forces of law and order). Four policy syndromes in terms of terrorist outcomes are selected, involving the number of: incidents, injuries, fatalities, and property damages. In addition, the modulating impact of two main policy variables are investigated, namely (i) security officers and the police and (ii) armed service personnel. Hence, there is an underpinning assumption that good governance practices embodied within the framework of the forces of law and order helps to lessen the potentially adverse consequences of terrorism. Therefore, the research question which the study aims to answer is: "can the forces of law and order effectively modulate the effect of terrorism externalities on tourist arrivals across the world?"

The closest strand of the literature to the present study has focused on using foreign aid policy to limit the consequences of terrorism on macroeconomic variables (Bandyopadhyay et al., 2014; Asongu \& Nwachukwu, 2017). We deviate from this stream of literature by focusing on internal policies and the tourism sector. 


\section{Data and methodology}

The study focuses on a sample of 163 countries using data for the period 2010 to 2015. The data is obtained from a plethora of sources disclosed in $\mathrm{T}$ able 1 . The choice of geographical and temporal scopes of the study is contingent on data availability constraints. This justification is in accordance with recent literature that has used the same dataset (Asongu, 2018; Asongu \& Acha-Anyi, 2018).

The dependent variable is the number of tourist arrivals. The insecurity variables or policy syndromes are captured with four main terrorism externalities, namely the number of: incidents, injuries, fatalities and property damages. The modulating policy variables are the forces of law and order comprising: (i) security officers and the police and (ii) armed service personnel. The selection of these policy syndromes and policy variables is motivated by the literature on the determinants of violence, crimes, terrorism and tourism (see Freytag et al., 2011; GPI, 2016; Asongu \& Kodila-Tedika, 2016, 2017; Asongu et al., 2018). The adopted control variables include: homicide, violent demonstrations and incarcerations ${ }^{1}$. These indicators are consistent with the extant studies on tourist arrivals (Saha \& Yap, 2013; Alvarez \& Campo, 2014; Mehmood et al., 2016). The first-two variables (i.e. homicide and violent demonstrations) are anticipated to negatively influence tourist arrivals while the third (i.e. incarcerations) is expected to positively affect tourism. This is essentially because the first-two increase perceived risk to life in the destination country whereas the third reduces the perceived risk.

\footnotetext{
${ }^{1}$ By incarcerations, the study refers to all types of lawful convictions (i.e. those related to terrorist activity as well as those related to drug, petty thefts, inter alia).
} 
Table 1: Definition of variables

\begin{tabular}{|c|c|}
\hline Variables & Definitions of variables and sources \\
\hline Tourism & The number of tourists arrivals \\
\hline Security Officers \& Police & $\begin{array}{l}\text { Number of internal security officers and police } \\
\text { per } 100,000 \text { people UNODC; EIU estimates }\end{array}$ \\
\hline Armed Services Personnel & $\begin{array}{l}\text { Number of armed services personnel per } 100,000 \text { people } \\
\text { The Military Balance, IISS }\end{array}$ \\
\hline Terrorism incidents & Logarithm $(1+$ base $)$ of Total number of terrorist incidents in a given year. \\
\hline Terrorism fatalities & $\begin{array}{l}\text { Logarithm }(1+\text { base }) \text { of Total number of fatalities caused by terrorists in a given } \\
\text { year }\end{array}$ \\
\hline Terrorism injuries & $\begin{array}{l}\text { Logarithm }(1+\text { base }) \text { of Total number of injuries caused by terrorists in a given } \\
\text { year }\end{array}$ \\
\hline $\begin{array}{l}\text { Terrorism-related property } \\
\text { damages }\end{array}$ & $\begin{array}{l}\text { Logarithm }(1+\text { base }) \text { of the measure of the total property damage from terrorist } \\
\text { incidents in a given year. }\end{array}$ \\
\hline Homicides & $\begin{array}{l}\text { Number of homicides per 100,000 people } \\
\text { United Nations Office on Drugs and Crime (UNODC) Surveys on Crime Trends } \\
\text { and the Operations of Criminal Justice Systems (CTS); EIU estimates }\end{array}$ \\
\hline Incarceration & $\begin{array}{l}\text { Number of jailed population per } 100,000 \text { people } \\
\text { World Prison Brief, International Centre for Prison Studies, University of Essex }\end{array}$ \\
\hline Violent demonstrations & $\begin{array}{l}\text { Likelihood of violent demonstrations } \\
\text { Qualitative assessment by EIU analysts }\end{array}$ \\
\hline
\end{tabular}

Uppsala Conflict Data Program (UCDP). The Institute for Economics and Peace (IEP).The Economic Intelligence Unit (EIU). United Nations Peacekeeping Funding (UNPKF). GDP: Gross Domestic Product. The International Institute for Strategic Studies (IISS).

Table 1 provides the definitions and sources of variables. We note that the summary statistics of the selected variables indicate that standard deviation of the dependent variable is much higher than the mean. Such evidence of over-dispersion of data on the outcome variable suggests that a Negative Binomial model is a more appropriate estimation technique. Consistent with Choi and Luo (2013) and Choi (2015), a Negative Binomial regression is used because the data is positively skewed. Moreover, in line with recent literature, the independent variables are lagged by one year in order to correct for potential endogeneity (Mlachila et al., 2017). Owing to lack of space, the summary statistics, correlation matrix and model specification are available upon request.

\section{Empirical results}

This section presents and discusses the empirical findings. Whereas Table 2 shows findings pertaining to security officers and the police, those in Table 3 relate to armed service personnel. 
Table 2: Negative binomial regressions with security officers and police

\begin{tabular}{|c|c|c|c|c|c|c|c|c|}
\hline \multirow[b]{3}{*}{ Constant } & \multicolumn{8}{|c|}{ Dependent variable: Number of Tourist Arrivals } \\
\hline & \multicolumn{4}{|c|}{ Without control variables } & \multicolumn{4}{|c|}{ With control variables } \\
\hline & $\begin{array}{l}15.606 * * * \\
(0.000)\end{array}$ & $\begin{array}{l}15.755 * * * \\
(0.000)\end{array}$ & $\begin{array}{l}15.641 * * * \\
(0.000)\end{array}$ & $\begin{array}{l}15.553 * * * \\
(0.000)\end{array}$ & $\begin{array}{l}16.778 * * * \\
(0.000)\end{array}$ & $\begin{array}{l}16.633 * * * \\
(0.000)\end{array}$ & $\begin{array}{l}16.715^{* * * *} \\
(0.000)\end{array}$ & $\begin{array}{l}16.774 * * * \\
(0.000)\end{array}$ \\
\hline Security Officers \& Police(SOP)(-1) & $\begin{array}{l}-0.099 \\
(0.368)\end{array}$ & $\begin{array}{l}-0.0262 \\
(0.812)\end{array}$ & $\begin{array}{l}-0.028 \\
(0.802)\end{array}$ & $\begin{array}{l}-0.034 \\
(0.479)\end{array}$ & $\begin{array}{l}-0.087 \\
(0.352)\end{array}$ & $\begin{array}{l}0.003 \\
(0.971)\end{array}$ & $\begin{array}{l}-0.020 \\
(0.828)\end{array}$ & $\begin{array}{l}-0.017 \\
(0.840)\end{array}$ \\
\hline Terrorism incidents(-1) & $\begin{array}{l}0.080 \\
(0.613)\end{array}$ & --- & --- & --- & $\begin{array}{l}0.073 \\
(0.550)\end{array}$ & --- & --- & --- \\
\hline Terrorism fatalities(-1) & --- & $\begin{array}{l}-0.114 \\
(0.389)\end{array}$ & --- & --- & --- & $\begin{array}{l}0.665 \\
(0.048)\end{array}$ & --- & --- \\
\hline Terrorism injuries(-1) & --- & --- & $\begin{array}{l}0.029 \\
(0.806)\end{array}$ & --- & --- & --- & $\begin{array}{l}0.074 \\
(0.452)\end{array}$ & --- \\
\hline Terrorism-related property damages(-1) & --- & --- & --- & $\begin{array}{l}0.132 \\
(0.500)\end{array}$ & --- & --- & --- & $\begin{array}{l}0.123 \\
(0.482)\end{array}$ \\
\hline Terrorism incidents $\times \mathrm{SOP}(-1)$ & $\begin{array}{l}0.077 \\
(0.170)\end{array}$ & --- & --- & --- & $\begin{array}{l}0.082 * \\
(0.066)\end{array}$ & --- & --- & --- \\
\hline Terrorism fatalities $\times$ SOP $(-1)$ & --- & $\begin{array}{l}0.065 \\
(0.154)\end{array}$ & --- & --- & --- & $\begin{array}{l}0.038 \\
(0.333)\end{array}$ & --- & --- \\
\hline Terrorism injuries $\times \mathrm{SOP}(-1)$ & --- & --- & $\begin{array}{l}0.039 \\
(0.346)\end{array}$ & --- & --- & --- & $\begin{array}{l}0.035 \\
(0.303)\end{array}$ & --- \\
\hline $\begin{array}{l}\text { Terrorism-related property } \\
\text { damages } \times \operatorname{SOP}(-1)\end{array}$ & --- & --- & --- & $\begin{array}{l}0.064 \\
(0.345)\end{array}$ & --- & --- & --- & $\begin{array}{l}0.075 \\
(0.170)\end{array}$ \\
\hline Homicides(-1) & --- & --- & --- & --- & $\begin{array}{l}-0.508 * * * \\
(0.000)\end{array}$ & $\begin{array}{l}-\mathbf{0 . 5 8 3} * * * \\
(\mathbf{0 . 0 0 0 )}\end{array}$ & $\begin{array}{l}-0.556 * * * \\
(0.000)\end{array}$ & $\begin{array}{l}-0.523 * * * \\
(0.000)\end{array}$ \\
\hline Incarceration(-1) & --- & --- & --- & --- & $\begin{array}{l}0.641 * * * \\
(0.000)\end{array}$ & $\begin{array}{l}0.688 * * * \\
(0.000)\end{array}$ & $\begin{array}{l}0.664 * * * \\
(0.000)\end{array}$ & $\begin{array}{l}0.645 * * * \\
(0.000)\end{array}$ \\
\hline Violent demonstrations(-1) & --- & --- & --- & --- & $\begin{array}{l}-0.463 * * * \\
(0.000)\end{array}$ & $\begin{array}{l}-0.390 * * * \\
(0.000)\end{array}$ & $\begin{array}{l}-0.421 * * * \\
(0.000)\end{array}$ & $\begin{array}{l}-0.454 * * * \\
(0.000)\end{array}$ \\
\hline Armed Services Personnel(-1) & --- & --- & --- & --- & $\begin{array}{l}-0.137 \\
(0.187)\end{array}$ & $\begin{array}{l}-0.101 \\
(0.355)\end{array}$ & $\begin{array}{l}-0.118 \\
(0.274)\end{array}$ & $\begin{array}{l}-0.177 * \\
(0.090)\end{array}$ \\
\hline Net Effects & na & na & na & na & na & na & na & na \\
\hline Log likelihood & -9569.354 & -9593.458 & -9586.805 & -9576.902 & -9443.501 & -9470.4 & -9462.947 & -9451.660 \\
\hline Likelihood Ratio (LR) Chi-Square & $54.99 * * *$ & $6.78^{*}$ & $20.09 * * *$ & $39.89 * * *$ & $306.70 * * *$ & $252.90 * * *$ & $267.80 * * *$ & $290.38 * * *$ \\
\hline Alpha & $1.853 * * *$ & $1.962 * * *$ & $1.932 * * *$ & $1.887 * * *$ & $1.361 * * *$ & $1.456 * * *$ & $1.429 * * *$ & $1.389 * * *$ \\
\hline Observations & 580 & 580 & 580 & 580 & 580 & 580 & 580 & 580 \\
\hline
\end{tabular}

***,**,*: significance levels at $1 \%, 5 \%$ and $10 \%$ respectively. Mean value of Security Officers \& Police: 2.728 . Min and Maximum values of Security Officers \& Police are respectively 1.081 and 5.000. na: not applicable due to the insignificance of unconditional effects of insecurity variables and/or conditional effect from the interaction between the security policy variable and insecurity variables.

In both tables, the first panel is concerned with estimations that do not involve controls variables, while the second panel includes a conditioning information set. In order to examine the importance of forces of law and order in reducing the potential adverse impact of terrorism externalities on tourism, corresponding net effects are computed in conformity with arguments in recent literature (Tchamyou, 2018). 
Table 3: Negative binomial regressions with armed service personnel

\begin{tabular}{|c|c|c|c|c|c|c|c|c|}
\hline \multirow[b]{3}{*}{ Constant } & \multicolumn{8}{|c|}{ Dependent variable: Number of Tourist Arrivals } \\
\hline & \multicolumn{4}{|c|}{ Without control variables } & \multicolumn{4}{|c|}{ With control variables } \\
\hline & $\begin{array}{l}14.655 * * * \\
(0.000)\end{array}$ & $\begin{array}{l}15.289 * * * \\
(0.000)\end{array}$ & $\begin{array}{l}14.953 * * * \\
(0.000)\end{array}$ & $\begin{array}{l}14.932 * * * \\
(0.000)\end{array}$ & $\begin{array}{l}16.165 * * * \\
(0.000)\end{array}$ & $\begin{array}{l}16.338 * * * \\
(0.000)\end{array}$ & $\begin{array}{l}16.305 * * * \\
(0.000)\end{array}$ & $\begin{array}{l}16.343 * * * \\
(0.000)\end{array}$ \\
\hline Armed Services Personnel (ASP) (-1) & $\begin{array}{l}0.411 * * \\
(0.013)\end{array}$ & $\begin{array}{l}0.241 \\
(0.133)\end{array}$ & $\begin{array}{l}0.376 * * \\
(0.024)\end{array}$ & $\begin{array}{l}0.318^{* *} \\
(0.043)\end{array}$ & $\begin{array}{l}0.020 \\
(0.876)\end{array}$ & $\begin{array}{l}-0.037 \\
(0.760)\end{array}$ & $\begin{array}{l}0.00008 \\
(1.000)\end{array}$ & $\begin{array}{l}-0.058 \\
(0.638)\end{array}$ \\
\hline Terrorism incidents(-1) & $\begin{array}{l}0.659 * * * \\
(0.000)\end{array}$ & --- & --- & --- & $\begin{array}{l}0.454 * * * \\
(0.000)\end{array}$ & --- & --- & --- \\
\hline Terrorism fatalities(-1) & --- & $\begin{array}{l}0.138 \\
(0.379)\end{array}$ & --- & --- & --- & $\begin{array}{l}0.217^{* *} \\
(0.012)\end{array}$ & --- & --- \\
\hline Terrorism injuries(-1) & --- & --- & $\begin{array}{l}0.397 * * * \\
(0.000)\end{array}$ & --- & --- & --- & $\begin{array}{l}0.279 * * * \\
(0.000)\end{array}$ & --- \\
\hline Terrorism-related property damages(-1) & --- & --- & --- & $\begin{array}{l}0.707 * * * \\
(0.000)\end{array}$ & --- & --- & --- & $\begin{array}{l}0.497 * * * \\
(0.000)\end{array}$ \\
\hline Terrorism incidents $\times \mathrm{ASP}(-1)$ & $\begin{array}{l}-0.209 * * * \\
(0.002)\end{array}$ & --- & --- & --- & $\begin{array}{l}-0.088^{*} \\
(0.069)\end{array}$ & --- & --- & --- \\
\hline Terrorism fatalities $\times$ ASP $(-1)$ & --- & $\begin{array}{l}-0.039 \\
(0.662)\end{array}$ & --- & --- & --- & $\begin{array}{l}-0.039 \\
(0.399)\end{array}$ & --- & --- \\
\hline Terrorism injuries×ASP(-1) & --- & --- & $\begin{array}{l}-0.150 * * \\
(0.014)\end{array}$ & --- & --- & --- & $\begin{array}{l}-0.061 \\
(0.121)\end{array}$ & --- \\
\hline $\begin{array}{l}\text { Terrorism-related property } \\
\text { damages } \times \operatorname{ASP}(-1)\end{array}$ & --- & --- & --- & $\begin{array}{l}-0.220 * * * \\
(0.005)\end{array}$ & --- & --- & --- & $\begin{array}{l}-0.091 \\
(0.104)\end{array}$ \\
\hline Homicides(-1) & --- & --- & --- & --- & $\begin{array}{l}-0.498 * * * \\
(0.000)\end{array}$ & $\begin{array}{l}-0.577 * * * \\
(0.000)\end{array}$ & $\begin{array}{l}-0.545 * * * \\
(0.000)\end{array}$ & $\begin{array}{l}-0.514 * * * \\
(0.000)\end{array}$ \\
\hline Incarceration(-1) & --- & --- & --- & --- & $\begin{array}{l}0.641 * * * \\
(0.000)\end{array}$ & $\begin{array}{l}0.697 * * * \\
(0.000)\end{array}$ & $\begin{array}{l}0.667 * * * \\
(0.000)\end{array}$ & $\begin{array}{l}0.643 * * * \\
(0.000)\end{array}$ \\
\hline Violent demonstrations(-1) & --- & --- & --- & --- & $\begin{array}{l}-0.459 * * * \\
(0.000)\end{array}$ & $\begin{array}{l}-0.392 * * * \\
(0.000)\end{array}$ & $\begin{array}{l}-0.422 * * * \\
(0.000)\end{array}$ & $\begin{array}{l}-0.451 * * * \\
(0.000)\end{array}$ \\
\hline Security Officers \& Police (-1) & --- & --- & --- & --- & $\begin{array}{l}0.029 \\
(0.701)\end{array}$ & $\begin{array}{l}0.063 \\
(0.436)\end{array}$ & $\begin{array}{l}0.048 \\
(0.547)\end{array}$ & $\begin{array}{l}0.058 \\
(0.454)\end{array}$ \\
\hline Net effects & 0.314 & na & 0.149 & 0.344 & 0.308 & na & na & na \\
\hline $\begin{array}{l}\text { Log likelihood } \\
\text { Likelihood Ratio (LR) Chi-Square }\end{array}$ & $\begin{array}{l}-9565.688 \\
\mathbf{6 2 . 3 2} * * *\end{array}$ & $\begin{array}{l}-9593.480 \\
6.74 *\end{array}$ & $\begin{array}{l}-9584.007 \\
\mathbf{2 5 . 6 8 * * *}\end{array}$ & $\begin{array}{l}-9573.867 \\
\mathbf{4 5 . 9 6 * * *}\end{array}$ & $\begin{array}{l}-9443.793 \\
\mathbf{3 0 6 . 1 1} * * *\end{array}$ & $\begin{array}{l}-9470.558 \\
\mathbf{2 5 2 . 5 8 * * *}\end{array}$ & $\begin{array}{l}-9462.457 \\
\mathbf{2 6 8 . 7 8 * * *}\end{array}$ & $\begin{array}{l}-9451.469 \\
\mathbf{2 9 0 . 7 6 * * *}\end{array}$ \\
\hline Alpha & $1.837 * * *$ & $1.962 * * *$ & $1.919 * * *$ & $1.873 * * *$ & $1.362 * * *$ & $1.456 * * *$ & $1.427 * * *$ & $1.388 * * *$ \\
\hline Observations & 580 & 580 & 580 & 580 & 580 & 580 & 580 & 580 \\
\hline
\end{tabular}

***,**,*: significance levels at $1 \%, 5 \%$ and $10 \%$ respectively. Armed S. Personnel: Armed Service Personnel. Mean value of Armed Service Personnel: 1.648. Min and Maximum values of Armed Service Personnel are respectively 1.000 and 5.000. na: not applicable due to the insignificance of unconditional effects of insecurity variables and/or conditional effect from the interaction between the security policy variable and insecurity variables.

Given the above emphasis, in the second column of Table 3, the net effect from the role of armed service personnel in modulating the possible adverse effects of terrorism incidences is $0.314([-0.209 \times 1.648]+[0.659])$, where: 0.659 is the unconditional effect from terrorist events; 1.648 is the mean value of armed service personneland -0.209 is the conditional effect from the interaction between terrorist attacks and armed service personnel. It is important to note that the effects (unconditional and conditional) should be interpreted from a holistic perspective in order to comprehensively assess the role of armed service personnel in controlling the possible damaging effects of terrorist incidences on tourist arrivals.

In the light of above computational insights, in Table 2, we may infer that security officers and police do not significantly affect terrorism outcomes in their relationship with tourist arrivals. This is presumably because net effects are not applicable due to consistently 
insignificant conditional and unconditional effects. Conversely, in Table 3 pertaining to armed service personnel, positive net effects are largely apparent in the relationship between tourist arrivals and three out of our four selected terrorism externalities, notably the number of: incidents, injuries and property damages. Net effects cannot be computed for the interconnections with terrorism fatalities for the same reason as in Table 2.

The significant control variables have the expected signs. Accordingly, in both tables, violent demonstrations and homicides have a negative effect on tourist arrivals while the number of incarcerations displays the opposite effect.

\section{Concluding implications and future research directions}

In this paper, we investigated the role of security officers, the police and armed service personnel in dampening the effect of terrorism externalities on tourist arrivals. From the findings it is obvious that the fight against the possible destructive influence of terrorist attacks on development outcomes is beyond the scope of internal security officers and the police. In other words, security officers and the police by themselves are necessary but not sufficient to mitigate the adverse consequences of terrorism. It is important to note that the police and security officers within the context of the study represent personnel in public agencies whose principal functions are the prevention, detection and investigation of crime and the apprehension of alleged offenders. Conversely, armed service personnel entail all service men and women on full-time duty in the army, navy, air force and joint forces (including conscripts and long-term assignments from the reserves). Thus, our results effectively capture the relevance of a military dimension in the fight against terrorism. To this end, assessing how military expenditure influences the harmful development externalities of terrorism is a worthwhile future research direction. 


\section{References}

Alvarez, M. D. \& Campo, S., (2014).“The Influence of Political Conflicts on Country Image and Intention to visit: A Study of Israel's Image." Tourism Management, 40(February), pp. 70-78.

Asongu, S. A., (2018). "Persistence in Incarcerations: Global Comparative Evidence", Journal of Criminological Research, Policy and Practice, 4(2), pp.136-147.

Asongu, S. A., \& Acha-Anyi, P. N., (2018). "The Murder Epidemic: A Global Comparative Study”, International Criminal Justice Review.DOI: 10.1177/1057567718759584.

Asongu, S. A., \& Kodila-Tedika, O., (2016). "Fighting African conflicts and crimes: which governance tools matter?",International Journal of Social Economics, 43(5), pp. 466-485.

Asongu, S. A., \& Kodila-Tedika, O., (2017).“Trade, aid and terror”, International Journal of Development Issues, 16(1), pp. 2-24.

Asongu, S. A., Tchamyou, V. S., Minkoua, N, J. R., Asongu, N., \&Tchamyou, N. P., (2018a). "Fighting terrorism in Africa: Benchmarking policy harmonization", Physica A: Statistical Mechanics and its Applications, 492(February), pp. 1931-1957.

Asongu, S. A., \& Nwachukwu, J. C., (2017). "Fuel Exports, Aid and Terrorism", Multinational Business Review. 25(3), pp. 239-267.

Asongu, S. A., \& Nwachukwu, J. C., \& Pyke, C., (2018). "The Right to Life: Global Evidence on the Role of Security Officers and the Police in Modulating the Effect of Insecurity on Homicide", Social Indicators Research. DOI: 10.1007/s11205-018-1992-2

Bandyopadhyay, S., Sandler, T., \&Younas, J., (2014). "Foreign direct investment, aid, and terrorism", Oxford Economic Papers, 66(1), pp. 25-50.

Choi, S-W., (2015). "Economic growth and terrorism: domestic, international, and suicide", Oxford Economic Papers, 67(1), pp. 157-181.

Choi, S-W., \& Luo, S., (2013). "Economic Sanctions, Poverty, and International Terrorism: An Empirical Analysis," International Interactions, 39(2), pp.217-245.

Freytag, A., Kruger, J. J., Meierrieks, D., \& Schneider, F., (2011).“The origins of terrorism: Cross-country estimates of socio-economic determinants of terrorism", The European Journal of Political Economy, 27(Supplement 1), pp. S5-S16.

GTI (2014). "Global Terrorism Index: Measuring and Understanding the Impact of Terrorism", Institute for Economics and Peace, pp. 2-90.

http://www.visionofhumanity.org/sites/default/files/Global\%20Terrorism\%20Index\%20Repor t\%202014_0.pdf (Accessed: 28/04/2015).

GPI (2016).Global Peace Index 2016. Institute for Economics \& Peace. 
Mehmood, S., Ahmad, Z. \& Khan, A. A., (2016).“Dynamic Relationships between Tourist Arrivals, Immigrants, and Crimes in the United States."Tourism Management, 54(June), pp.383-392.

Mlachila, M., Tapsoba, R., \&Tapsoba, S. J. A., (2017). “A Quality of Growth Index for Developing Countries: A Proposal”, Social Indicators Research,134(2), pp 675-710.

Saha, S. \& Yap, G., (2013).“The Moderation Effects of Political Instability and Terrorism on Tourism Development.”Journal of Travel Research, 53(4), pp. 509-521.

Tchamyou, V.S., (2018). "Education, Lifelong learning, Inequality and Financial access: Evidence from African countries". Contemporary Social Science. DOI:

$10.1080 / 21582041.2018 .1433314$. 